\title{
The rules of the game in transition: how informal institutions work in South East Europe
}

\author{
Alena Ledeneva and Adnan Efendic
}

\begin{abstract}
This chapter reviews the literature on the interaction between formal and informal institutions and undertakes some empirical tests for the validity of frequent claims about the substitutive role of informal institutions. We address two questions: "what works when the formal institutions do not?' and 'to what extent do formal institutions (operationalised as trust in formal rules and procedures) constitute real constraints in South East European societies with a strong hold of personalised trust and reliance on personal connections.'
\end{abstract}

To answer these questions we analyse survey data from eight countries of South East Europe on the interaction between formal and informal institutions. When formal rules fail to be effective, social norms of reliance on "trusted people and connections" predominate as a default (substitutive) option. However, there are limits to empirical testing of the existing typologies of the formal-informal interaction, because of the complexity of factors surrounding the workings of informal networks that channel and enable such interactions.

Our findings suggest that both the general public and entrepreneurs rely on personalised trust and invest into informal networking, with entrepreneurs doing so more actively in order to reduce the uncertainty and compensate for the ineffectiveness of formal institutions. The quantitative evidence suggests that maintaining informal networks incur substantial economic costs, which should not be ignored by researchers and policy makers. The qualitative data suggest that without understanding of the strong grip of "trusted people and connections," it is not possible to model resource allocation, re-distribution and economic behaviour in the SEE region. 


\section{Introduction}

Neoinstitutional theory defines institutions as rules of the game, or 'the humanely devised constraints that structure political, economic and social interaction. They consist of both informal constraints (sanctions, taboos, customs, traditions, and codes of conduct), and formal rules (constitutions, laws, property rights)' (North, 1991: 97). The effectiveness of such institutions is associated with their regulatory and enforcement capacity (Scott, 2004). While the idea of formal and informal institutions is widely used in social sciences, and the effectiveness of formal institutions is monitored consistently, there are few empirical studies on the effects of informal institutions, and little empirical data on the interaction between formal and informal institutions. With the exception of the INFORM project: Closing the gap between formal and informal institutions in the Balkans (2016-2019) ${ }^{1}$, the quantitative data on informal institutions is rare and not integrated with the data on formal institutions.

The idea of closing the gap between formal and informal institutions is especially relevant to societies in transition where legal rules change fast and are imposed top-down, often under the pressure of international organisations and donors. This often results in clashes with existing or local social norms. Such clashes put an enormous burden on people, asked to transform their behaviour, and on governments, required to implement changes in order to score well in international rankings. In SEE countries, the clash of the Europeanisation reforms with people's resistance to change have become associated with policy failures of 'over-regulation and underenforcement,' otherwise known as the 'policy implementation gap.' The respective roles of formal and informal institutions in closing the implementation gap are still to be addressed (Gordy and Efendic, 2019).

It is widely recognized that a 'good institutional arrangement' is one where formal and informal institutions are not divergent, or in conflict (De Soto, 2000). In other words, legal norms are in harmony with social norms (Pejovich, 1999), both are embedded in human behaviour, and their outcome is convergent (Helmke and Levitsky, 2004). Views may differ on whether such convergence can be described as complementary or substitutive (North, 1990; Brousseau and Glachant, 2008; Furubotn and Richter, 2005). The existing typologies of informal institutions that use such terminology, presume that informal institutions are secondary to the operations of the formal institutions and residual, i.e. everything that is not formal but passed the test of time is informal (Helmke and Levitsky, 2004; Lauth, 2007). The complexity of empirical data challenges such assumptions. It is convenient to presume that legal rules are enforced formally, by the state, organisations, or formal hierarchies, while social norms are enforced informally, via families, peer circles and networks. Yet, in effect, these are hard to separate, as formal constraints tend to be enforced only if there is informal pressure to enforce them, or can exist only on paper. The reverse is also true: informal pressure may only emerge because there is a formal framework at work.

\footnotetext{
${ }^{1}$ https://www.ucl.ac.uk/ssees/research/funded-research-projects/inform/en/
} 
The INFORM evidence from transition economies presents additional puzzles. Firstly, in SEE for example, we witness multiple legislative changes that do not get implemented (Gordy and Efendic, 2019). It raises questions on whether codified formal rules can qualify as 'formal institutions,' if they are not enforced and do not constitute formal constraints as such (for examples of these see: Sakwa, 2007; Ledeneva 2001; Ginsburg and Simpser, 2013; Newton, 2017).

Secondly, the constraints posed by informal institutions need unpacking, as the enforcement of social norms, sometimes referred to as unwritten or informal rules, vary significantly and is context-bound. "Informal rules, then, are traditions, customs, moral values, religious beliefs and all the other norms of behaviour that have emerged spontaneously, survived the test of time and served to bind the generations" (Pejovich, 2008:11).

Thirdly, in SEE and other transitional contexts, we witness practices and informal exchanges, deemed to be path dependent, traditional or linked to communism, while in fact they are temporal reactions to the post-communist reforms (Ledeneva, 2006, 2008; Henig and Makovicky, 2017). A common assumption about transitional societies has been that 'economies of favours,' compensating for the 'economies of shortage' and defects in centralised planning and socialist systems of resources allocation and privileges, would become redundant once liberal reforms had opened markets and established democracies. However, the development of informal institutions in transition does not seem to follow this logic.

Fourthly, the role of networks in the enforcement of both formal rules and informal norms is not sufficiently integrated in the conceptualisation of the formal-informal interaction. The informal transaction costs associated with dense networks are often disregarded, and informal networks are not seen as effective for enforcing formal constraints. A more balanced analysis of the transaction costs associated with informal networking is needed (Efendic \& Ledeneva, 2020).

These four points need to be addressed to understand the formal-informal interaction in transition societies. Empirically, we need proxies for the degree of institutionalisation of both formal rules and informal norms and the degree for their enforcement; a degree of independence or derivativeness (norms and practices as causal or consequential to the outcome of reforms); and a measure of sociability or instrumentality of networks. Conceptually, we need models accommodating such complexity and change (Andersson, 2008; Brousseau and Glachant, 2008; Ledeneva et al., 2018). The exiting literature on the interaction of formal and informal institutions is not balanced: the scholars either give the primacy to formal institutions and residual status to informal institutions, or informal institutions are studied without much consideration of their formal frameworks. Revisiting the conceptualisation of the formalinformal interaction is thus a necessary starting point.

This chapter starts with a discussion of the existing typologies of interaction between formal and informal institutions; it outlines key features of the institutional framework in SEE region; offers some empirical tests for the validity of claims about a dominant substitutive role of 
informal institutions; and presents preliminary findings. We tackle the questions, 'what works when the formal institutions do not?' and 'to what extent changing formal institutions (operationalised as trust into formal rules and procedures) constitute real constraints in the societies with a strong hold of informal norms (operationalised as reliance on personal connections)?'

We rely on evidence from eight countries of South East Europe (SEE) and scrutinise the data quantitatively and qualitatively. The investigation is based on representative survey data collected among the general public (6,000 respondents) and qualitative data collected among entrepreneurs in SEE (70 interviews), specifically in Albania, Bosnia and Herzegovina, Croatia, Kosovo, Montenegro, North Macedonia, Serbia and Slovenia. We conclude that both the general public and entrepreneurs invest much time and resources into informal networking to reduce the uncertainty and compensate for the inefficiency of formal institutions. The quantitative evidence suggests that maintaining informal networks is associated with substantial economic costs. The qualitative evidence emphasizes the predominant role of particular relationships over universal rules, or reliance on "trusted people and connections," without which it is not possible to model economic behaviour in particularistic contexts.

In the next section, we define 'informal institutions' and revisit the existing conceptualisations of formal-informal interaction and re-balance them by giving more explanatory power to informal institutions.

\section{The rules of the game: revisiting formal and informal institutions}

Institutions are "perfectly analogous to the rules of the game in a competitive team sport. That is, they consist of formal written rules as well as typically unwritten codes of conduct that underline and supplement formal rules, such as not deliberately injuring a key player on the opposite team. And as this analogy would imply, the rules and informal codes are sometimes violated and punishment is enacted. Taken together, the formal and informal rules and the type and effectiveness of enforcement shape the whole character of the game" (North, 1990: 4). Compressing this amalgamation of rules, codes, their interaction, and their enforcement allowed North to revolutionise the notion of institution, now associated with neoinstitutionalism.

The complexity of such conceptualisation that includes rules, enforcing mechanisms, and players, however, does not lend itself easily to empirical research. Hence, the constituents of institutions - formal and informal constraints have come to be considered apart from each other, and from their interaction and enforcement. Informal institutions are regarded as "conventions, norms of behaviour, and self-imposed codes of conduct" (North, 1995: 23), which produce constraints to reduce uncertainty in human interaction, whereas formal constraints are associated with rules and specifications, statutes and common laws, and constitutions. However, "[the] difference between informal and formal constraints is one of degree. Envision a continuum of taboos, customs and traditions at one end to written constitutions at the other." Instead of separate entities, North speaks of a continuum of constraints, which can be depicted as in Figure 1 by a dotted line from formal rules to informal norms. 
Figure 1. INFORM model of the interaction of formal and informal institutions - step 1.

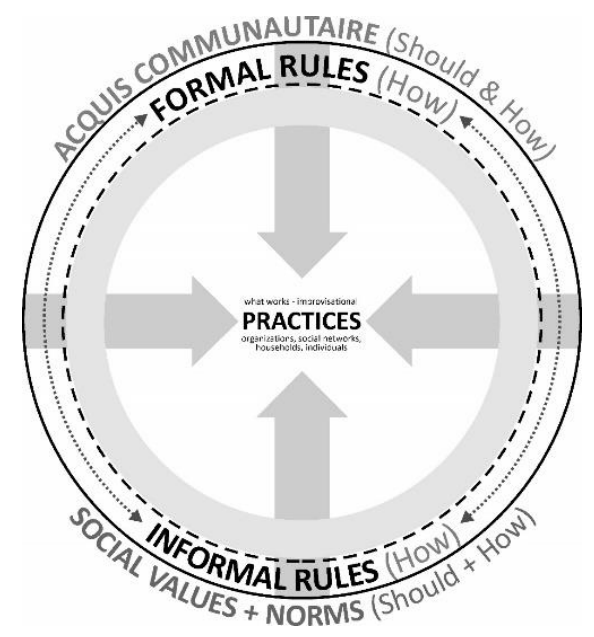

North (1995: 37) acknowledges the role of informal institutions in the functioning of formal institutions and presumes their amalgamation. Because of complexity, "incompleteness of information" and the need to "coordinate human interactions," informal institutions are necessary and include: “(1) extensions, elaborations and modifications of formal rules, (2) socially sanctioned norms of behaviour, (3) internally enforced standards of conduct" (North, 1990: 40). Some well-known examples would include (1) the use of progress-pushers to enable planned economies to reach their targets (2) widely spread denunciation practices but also social norm of contempt for anonymous letters and whistle-blowers; (3) adhering to the notions of friendships and voluntary acceptance of obligations to help, to "give away the last shirt" to a friend even where it involved formal rule-breaking.

The editors of The International Handbook of Informal Governance observe that various authors attach the adjective 'informal' to a wide range of conceptions: politics, arrangements, networks, institutions, organisations, norms, rules, activity or influence (Christiansen and Neuhold 2012). They distinguish at least three separate usages of it: first, the designation of the framework within which decisions are taken as being informal (institutions, organisations, networks); second, the identification of the process or procedure through which policies are made as being informal (politics, arrangements, activity); and, third, the classification of the outcome of any such process as being informal (rules, norms, influence). Adding the adjective "informal" to a subject matter reveals some important dimensions of its analysis, but often conceals the intricacies of the formal-informal interaction. Thus, definitions of informal institutions, explicitly or implicitly, presume a certain perspective on the interaction between formal rules and informal norms, often determined by a particular disciplinary method. Four perspectives can be distinguished:

- Normative, top-down perspective: formal (legal, prescriptive) = good, informal (cultural, slow to change) $=$ bad, participants are not given a voice. Prescriptions for formalisation and crusades against informality are taken for granted (see overview in Polese, 2015). 
- Residual perspective: formal and informal institutions are co-existent, but priority/legitimacy, primacy is given to the formal. Types of informal institutions, for example, are determined by the (in)effectiveness of formal and convergence/divergence of outcomes of the formal and informal institutions (e.g. Helmke and Levitsky, 2004).

- Symbiotic perspective: formal and informal institutions are co-dependent, presuming a balance between formal and informal institutions, as in the yin/yang approach (e.g. Fang, 2012).

- Inductive, bottom-up perspective: informal institutions are given primacy, and formal institutions are seen as an outcome of a historical process of the institutionalisation of informal norms. "Informal institutions can also serve as templates for formal institutions. Informal rules may generate precedents and prevalent practices that are then formalized for efficiency's sake, as with the rise of private property and the incorporation of capitalist entrepreneurs into the Communist Party in China" (Tsai, 2006, cited in Grzymala-Busse, 2010; see also de Soto 1989). Participants are given voice and the formal institutions often shift out of the focus of inquiry, as in the majority of ethnographic studies of informal practices.

These perspectives are often implicit in disciplinary method or focus of inquiry. The limitations of each perspective creates a niche for an interdisciplinary approach to grasp the complexity of the formal-informal interaction. However, in order to focus on the interaction of formal and informal institutions in the context of transition economies, we first need to resolve the four puzzles outlined in the introduction.

\subsection{Differentiating rules and constraints: the 'enforcement belt'}

North (1990) identifies formal institutions (formal rules) with formal constraints and informal institutions (informal norms) with informal constraints. However, for understanding communist, post-communist, authoritarian and transitional contexts, it is essential to envisage that both formal rules and informal norms do not always constitute real constraints, as many of them are meant to remain the façade of economic and political regimes or traditional practices. In other words: not all formally codified rules constitute formal constraints, and those which do might not necessarily do so with the consistency and predictability we associate with formal institutions. Moreover, relying on the record of codified rules would not produce sufficient data on the workings of an economy. Similarly, there can be informal rules, which never become constraints - this is how Bourdieu got the idea of strategies - he noticed that there are matrimonial rules in Algeria, which everybody knows, but only few follow. Both formal and informal rules can thus be "empty shells" (Dimitrova, 2010). As depicted on Figure 2, the INFORM model differentiates between formal rules and formal constraints in order to point out the issue of the 'under-enforcement' of formal institutions in transition contexts, as well as between social norms and informal constraints in order to point out the context-bound nature of the social norms and their partial enforcement. The emphasis here is on the 'enforcement belt', that allows us to capture which rules and norms constitute actual constraints. 
Figure 2. INFORM model of the interaction of formal and informal institutions - step 2.

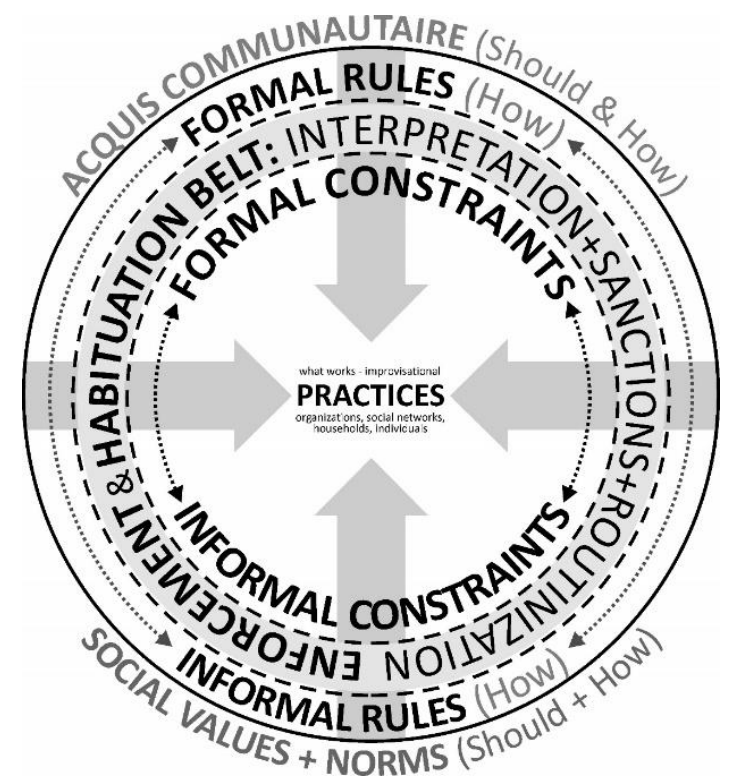

The main limitation of defining institutions as constraints is that North ignores the enabling aspects of institutions. "Institutions do indeed forbid many activities, but they equally make possible an enormous range of activities that would be impossible-inconceivable-in their absence: that is, they are always and everywhere liberating as well as limiting" (Neale 1993: 423). The ambivalent nature of constraints and their enabling power is essential for understanding the dual functionality of informal practices that both support and subvert the formal rules and informal norms that shape them (Ledeneva et al., 2018, Vol. 2: 3-5). Hodgson (2006) states that institutions both enable and constrain behaviour, whereas Searle (2005) suggests that the role of institutions is not to constrain people but to create new kinds of power relationships, which are enabling.

\subsection{Enforcement of formal rules and informal norms: the effectiveness of constraints}

Formal rules are enforced primarily by hierarchies: state organisations like courts, legislatures, bureaucracies and state enforced rules such as constitutions, laws, and regulations. Informal norms include conventions, codes of behaviour, traditions, cultural norms, religious beliefs, moral norms, habits and are enforced by families, trust circles and networks, or selfenforcement. These are passed from one generation to another through various transmission channels such as imitation, oral tradition and teaching (Tonoyan et al., 2010), and represent an "old ethos, the hand of the past or the carriers of history" (Pejovich, 1999: 166), associated with the phenomenon of path dependency in transitions.

It is often presumed that formal rules are more important because the risks and penalties associated with their violation are more considerable. However, the enforcement of informal norms is sometimes more efficient as it is grounded in daily interactions, self-enforcement, and subtle mechanisms that may not be visible. They are transferred from generations to generations (Pejovich, 2008) and may be just as important determinant of socio-economic environment as 
formal institutions (Knowles and Weatherston, 2006; Tabellini, 2010). Hence, the presence of informal institutions is a strong determinant of development (Williamson, 2009). This especially applies to co-coordinating activities where the costs of writing and enforcing contracts are high (Pollitt, 2002), or where "formal institutions exist on paper but are ineffective in practice" (Helmke and Levitsky, 2004: 730). However, informal institutions can be also inefficient; informal institutional voids appear with inability of norms, values and beliefs to facilitate stable, efficient and effective transactions (Webb et al., 2019). Whereas formal institutions might resemble each other in different societies, the informal institutions in which people are socialised and that they learn to respect, are seen as specific, cultural and emerging bottom up.

\subsection{Differentiating informal institutions from other informal regularities: "trusted people and connection" vs. informal networking in SEE}

Helmke and Levitsky define informal institutions as “... socially shared rules, usually unwritten, that are created, communicated, and enforced outside of officially sanctioned channels" (2004, p. 727). An example from the Soviet Union, fitting this definition, is an effective and self-enforced set of norms associated with friendship, mutual help and social cooperation (us vs. them). In SEE region, we establish a central role of the so-called "trusted people and connections' for compensating or substituting the failure of formal institutions to operate effectively. According to a widely cited typology of informal institutions, both complementary and substitutive types are related to the convergent outcomes of formal and informal institutions (see Table 1), whereas the outcomes of formal and informal institutions in SEE are divergent (i.e. there is a gap between formal rules and informal norms). It is thus crucial to emphasize that our hypothesis that the informal norms act as substitutes for the failure of formal institutions does not imply the convergent outcomes of formal and informal institutions in SEE. 
Table 1 Types of informal institutions

\begin{tabular}{|l|l|l|}
\hline Outcomes & $\begin{array}{l}\text { Effective formal } \\
\text { institutions }\end{array}$ & $\begin{array}{l}\text { Ineffective formal } \\
\text { institutions }\end{array}$ \\
\hline Convergent & Complementary & Substitutive \\
\hline Divergent & Accommodating & Competing \\
\hline
\end{tabular}

In order to qualify the SEE region case, we had to look deeper into the typology of informal institutions, proposed by Helmke and Levitsky (2004). In the matrix above, informal institutions are perceived to be a dependent variable, with an independent variable - formal institutions and their effectiveness - given primacy. The convergent and divergent types of outcomes do not constitute an independent variable as they are intrinsically linked to the first one. Four types of informal institutions are then presented: accommodating, competing, complementary and substitutive relationships. This matrix is consistent with the focus of political science on formal institutions, which somewhat reverses the historical logic of their formation. An example of paving pathways in a park illustrates the point. If the pavements are laid beautifully but in a top-down fashion, without taking into account the bottom-up footpaths that had been in use for generations, the situation of convergence might never occur. Paving the existing footpaths will reduce the transaction costs for their users and the possibility of divergence.

- Complementary informal institutions mean that formal and informal institutions coexist, and informal institutions might serve as a foundation for effective formal institutions. This is clearly not the cases for the SEE.

- Substitutive informal institutions are compatible with formal institutions, but do not engage with them: they operate in environments where formal rules are not routinely enforced, such as local micro-credit schemes or rotational cooperation in rural areas (see Ledeneva et al., 2018). Substitutive institutions aim to achieve what formal institutions failed to achieve, but not by relying on informal contacts for getting things done or circumventing procedures within the remit of formal institutions.

When the outcomes of the informal and formal institutions (effective or ineffective) are divergent, which would primarily be the case of the SEE countries, the types of interaction are:

- Competing informal institutions coexist with ineffective formal institutions. These informal institutions are incompatible with the formal rules and are often found in postcolonial contexts in which formal institutions were imposed on indigenous rules and authority structures. This type would qualify to describe the situation in the SEE region, where external legal norms are imposed on traditional norms and customs.

- Accommodating informal institutions alter the substantive effects of formal rules, but without directly violating them. This, for example, includes blat in the Soviet Union, 'because strict adherence to the formal rules governing Soviet political and economic 
life did not allow enterprises to fulfil state targets or permit individuals to meet basic needs, a set of informal norms emerged in which individuals met these goals through personal networks' (from Ledeneva, 1998 cited in Helmke and Levitsky, 2004).

The Helmky-Levitsky typology is widely cited in the literature, and rightly so. Despite the imbalance between formal and informal institutions it embodies, the typology points in the right direction for exploring the formal-informal interaction. In fact, their four types of informal institutions would work much better as four types of interaction, but the matrix should result from cross-tabulating types of formal institutions with types of informal institutions.

In order to focus on the interaction between formal and informal institutions specifically, we have devised an INFORM theoretical model that fits this empirical agenda much better. According to the INFORM model, both formal and informal institutions will only constitute constraints if they are effectively enforced. Needless to say, there will be formal rules that remain on paper and social norms that can be ignored without sanctions. In our study, however, we focus on informal institutions which are effective (i.e. enforced, sanctioned, and constitute informal constraints) and serve to deliver what formal institutions cannot (Webb et al., 2019). We operationalise these as relatively stable circles of "trusted people and connections" that engage in problem solving, perform economic functions, and execute informal pressure on its members (Ledeneva, 2008; Efendic et al., 2011; Efendic \& Ledeneva, 2020). These are different from socially shared norms, usually unwritten' by the fact that they are enforced (actually make it through the 'enforcement belt') and thus constitute real informal constraints for economic behaviour (see Figure 2).

\subsection{Stability of norms vs. temporality of practices: capturing interactions between formal and informal institutions}

Neither formal nor informal institutions are static, they evolve/change over time (North, 1990; Raiser, 2001; Jutting, 2003; Brousseau and Glachant, 2008; Hinings and Malhotra, 2008; Nelson, 2008; Ebner, 2008; Harriss, 2008; Acemoglu and Robinson, 2010; Efendic and Pugh, 2015). The reasons for institutional changes are multiple: from incremental and hardly noticeable to geopolitical, such as the end of communism in Central and East Europe, collapse of the Soviet Union, and breakdown of former Yugoslavia. For example: existing organisations influence institutional change; political forces are very often invoked in the dynamics of institutional processes; economic reality sometimes provokes changes; outsiders can promote institutional changes; sometimes almost the whole institutional environment is changed as in the case of transition economies during their evolution from centrally-planned systems towards market oriented economies. Finally, revolutions or wars, i.e. "discontinuous institutional change" (North, 1990: 89) may result in changes of institutional frameworks, which happened in some countries of SEE, and to the biggest extent in Bosnia and Herzegovina (Efendic, 2016). However, institutions should have durability as well, in order to be credible and acceptable to agents (Accemoglu, 2009); accordingly, there is continuous tension between the need for persistence and change in institutions (Andersson, 2008; Acemoglu, 2009). 
A change in institutions may be caused by variations in formal rules, informal norms, as well as by changes in enforcement (North, 1990), which implies that institutional change may be a very sophisticated process (Brousseau and Glachant, 2008; Opper, 2008). We probably still have rather partial knowledge of how institutions change (Shirley, 2008). However, the literature suggests that informal institutions are more stable than formal (North, 1990; Williamson, 2000; Pejovich, 2008; Ebner, 2008), though this does not mean that some social norms may not change very quickly. ${ }^{2}$ Since informal institutions change (generally) slowly they are taken for granted in most institutional research (Williamson, 2000; Andersson, 2008) or focused upon in isolation from formal institutions as is the case with inductive, bottom-up approaches and ethnographic research. Because of difficulties in measurability, informal institutions have been a neglected dimension in empirical research (Raiser, 2001; Harris, 2008) and treated as a "residual category" conceptually (Helmke and Levitsky, 2004: 727; Cason et al., 2010).

If we consider the potential causes and directions of changes, informal institutions tend to change gradually (driven by changes in social norms, customs, traditions, beliefs, habits, and values, i.e. "bottom-up"), while formal institutional change is determined by political forces in "top-down" (Easterly, 2008). The interaction of bottom-up and top-down forces is multidimensional and multilevel, which accounts for the complexity of institutional change. Since empirical studies cannot capture the complexity of institutional change, they have to be simplified and/or modified in various ways (Alston, 1996; Williamson, 2000; Fukuyama et al., 2007). Hence, a number of simplified institutional indicators and proxies are used in quantitative applied research. There are problems of measuring the quality or efficiency of formal institutions, but measuring informal institutions that relate to culture, mentalities, habits, trust, norms, conventions, codes, and informal networks is additionally challenging. Proxies for informal institutions used in empirical research are easy to challenge conceptually: examples include variables capturing culture (Tabellini, 2010; Williamson and Kerekes, 2011); civil society (Moers, 1999); or social capital (Jutting, 2003).

Both formal and informal constraints shape human behaviour - these are neither exogenous nor separate, as they are rooted in formal and informal institutions which are intertwined and in continuous interaction with one another (Redmond, 2005; Andersson, 2008; Webb et al., 2019). The ideal types of such interaction are mostly seen as complementary or substitutive in their influence on socio-economic outputs (North, 1990; Khan, 1995; Eggertsson, 1996; Raiser, 2001; Jutting, 2003; Furubotn and Richter, 2005, Fukuyama et al., 2007; Aidis et al., 2008; Brousseau and Glachant, 2008; Andersson, 2008; Nye, 2008; Efendic at al., 2011; Estrin and Prevezer, 2011; Bo Rothstein et al., 2013; Mungiu-Pippidi, 2015). Some authors provide empirical evidence on the explanatory role of informal institutions in shaping formal institutions (e.g. Casson et al., 2010; Grzymala-Busse, 2010; Williamson and Kerekes, 2011), leading us to conclude that this inter-relationship is very likely endogenous, which should not be ignored in applied research. In our study, we operationalise the interaction of formal and informal institutions by looking into the workings of informal networks, which activate personal 
relationships (exercise informal constraints) in order to circumvent formal constraints in the SEE region.

A rare mixed-method investigation of the interaction between formal institutions and informal norms was undertaken within the framework of the INFORM ${ }^{3}$ project implemented in SEE. The findings of this project indicate that informal norms in SEE tend to confront the top-down changes in formal institutions. The outcome of this clash results in the intense use of informal networking as an alternative mechanism of problem-solving and the rise of informal practices that point to the defects in workings of formal institutions. The willingness to engage into informal networking (i.e. invest time and money into socialising with subsequent "reliance on trusted people and connections") was found to be a common mechanism of problem solving. However, informal networking cannot be associated exclusively with ineffective formal rules, or with rational need for problem-solving. Informal institutions - social norms, cultural codes, customs, and traditions - have some explanatory power for the predominance of informal networking (Alesina and Giuliano, 2013, 2015; Cveticanin, 2012; Grødeland, 2013; Aliyev, 2015; Stanojevic and Stokanic, 2014).

\section{Specifics of the institutional framework in the SEE region: transaction costs of informal networks}

Informal networks are used differently in different cultures and institutional frameworks. In some contexts, informal networks are more oriented towards access to most basic needs and strategies of survival, in others they are associated with 'gaming the system' by elites (Ledeneva et al., 2018, Ch. 6). Trust-based networks can emerge in formal environments, and even be generated top-down or initiated bottom-up in organisations (Granovetter, 1985, Williamson, 1993, Möllering, 2014). For the purposes of our investigation, however, we focus on social networks that are biographical by-products of individuals ("trusted people and connections"). We refer to them as 'in-formal,' because they are relationship-based, yet aimed at bending the formal rules for competitive advantage.

In a society that operates under particularism, the use of informal networks, or reliance on connections and exchange of favours, are the key mode of resource allocation. In general terms, societies of the SEE qualify as 'particularist,' where relationships (and the pressure associated with them) mean more than rules, and "where individuals are treated differently according to particular ties or criteria" (Mungiu-Pippidi, 2015: 14). They differ from societies of ethical universalism - "where equal treatment applies to everyone regardless of the group to which one belongs"(Ibid.). As Mungiu-Pippidi (2015) argues, a society must transform its dominant social order from particularism to ethical universalism, in order to overcome the challenges of development and governance. Yet instead of engaging in a collective battle to alter the rules of the game to ethical universalism, a highly particularistic society coerces individuals to seek access to the privileged group and reap the benefits under the current rules of the game. Such individual compliance with particularism can be reduced if the equilibrium of opportunities 
and constraints is changed - if one can build a "critical mass" of individuals in favour of changing the rules of the game (Mungiu-Pippidi, 2015: 183).

Effective formal institutions reduce risks and the cost of transactions; both households and entrepreneurs would rationalise their transaction costs and reduce their burden where possible. In the meantime, in the absence of effective formal institutions in SEE, informal networks serve a variety of purposes, from exchange of information, experience and ideas between agents to the provision of goods, services, and favours, not freely accessible on the market. Maintaining such informal networks incurs costs (Efendic \& Ledeneva, 2019; 2020).

There seem to be a general consensus over the role of institutions in reducing transaction costs, even if definitions and calculations of transaction costs may vary significantly (Coarse, 2010). ${ }^{4}$ Transaction costs are presumed to go down once countries in transition had progressed further towards developed market economies, but for the time being monitoring the costs of informal networks can itself be a way of assessing the so-called 'implementation gap' (Blundo et al., 2013; Hudson and Marquette, 2015; Mungiu-Pippidi, 2015; Williams and Vorley, 2015; Baez Camargo \& Ledeneva, 2017). While the existing literature investigates predominantly the transaction costs of formal institutions or the benefits of social capital (e.g. Wallis and North, 1986), the question of costs of sustaining informal networks - social networks used for getting things done - remains largely neglected.

Informal constraints and cultural norms are based on particularistic, rather than universalistic assumptions, and remain underrepresented in the analyses of institutional frameworks. To reassess the balance, we associate the informal constraints with the costs they incur by using proxies of time and money (Efendic \& Ledeneva, 2020), but with important caveats about informal networks:

1) Whereas formal constraints are conceived to be universal and rational, informal networking serves to solve problems in particular contexts and tackle the complexity of social life.

2) Unlike social norms, informal networks are fluid and dynamic. Networks can change quickly; and stay dormant until a particular problem arises.

3) Similarly, to the formal hierarchies that grant access to resources, informal networks are just as valuable to their members. People care for, pay attention, and invest time and money to establish and maintain them.

4) Just as formal organisations are perceived to enforce formal rules, informal networks are perceived to channel informal constraints, peer pressure, and compliance with social norms. The potential of informal networks in channelling compliance with formal rules tends to be overlooked in policy-making. 


\section{Empirical analysis of formal-informal institutional interaction in SEE}

Now we move to the analysis of cross-country data and explore heterogeneity of formal and informal institutions in different countries by using representative micro data for individuals in the general public, supplemented with qualitative in-depth investigation of entrepreneurs ${ }^{5}$. Let us start with an outline of the existing assessments of the formal institutional environments in SEE (e.g. World Bank, 2018; Heritage Foundation, 2019). The region is characterised in most cases by institutional complexity, overlapping jurisdictions, government ineffectiveness and time-consuming processes, including some differences between the countries. In other words, there is room for further improvements of the formal institutional efficiency (see Table 2).

Table 2. Institutional environment in SEE looked through different institutional indices

\begin{tabular}{|c|c|c|c|c|c|c|c|}
\hline Country & $\begin{array}{c}\text { WB GE } \\
2018\end{array}$ & $\begin{array}{c}\text { WB RQ } \\
2018\end{array}$ & $\begin{array}{c}\text { WB RL } \\
2018\end{array}$ & $\begin{array}{c}\text { WB CC } \\
2018\end{array}$ & $\begin{array}{l}\text { IEF PP } \\
2019\end{array}$ & $\begin{array}{l}\text { IEF JE } \\
2019\end{array}$ & $\begin{array}{c}\text { IEF GI } \\
2019\end{array}$ \\
\hline Albania & 57.7 & 63.5 & 39.4 & 35.1 & 54.8 & 30.6 & 40.4 \\
\hline $\mathrm{BiH}$ & 28.4 & 45.2 & 46.6 & 31.7 & 40.2 & 37.9 & 30.2 \\
\hline Croatia & 69.2 & 68.3 & 63.0 & 60.1 & 66.0 & 42.9 & 38.6 \\
\hline Kosovo & 38.0 & 41.4 & 40.4 & 35.6 & 57.2 & 53.5 & 44.7 \\
\hline N. Macedonia & 55.8 & 71.6 & 43.8 & 42.3 & 65.1 & 60.7 & 44.7 \\
\hline Montenegro & 58.2 & 65.9 & 57.7 & 58.2 & 55.4 & 51.8 & 39.5 \\
\hline Serbia & 56.7 & 56.3 & 49.0 & 41.8 & 50.1 & 44.8 & 37.2 \\
\hline Slovenia & 83.2 & 75.0 & 82.7 & 80.8 & 76.4 & 46.5 & 53.6 \\
\hline \multicolumn{8}{|c|}{$\begin{array}{l}\text { Notes: WB refers to the World Banka Governance Indicators, the percentile rank ( } 0 \text { min to } 100 \text { max, indicates rank of } \\
\text { country among all countries in the world), which includes: GE - Government Effectiveness; RQ- Regulatory Quality; RL } \\
\text { - Rule of Law; CC - Control of Corruption. } \\
\text { IEF refers to the Heritage Foundation Index of Economic Freedom, (the scale is } 0 \text { min to } 100 \text { max), PP - Property Rights; } \\
\text { JE - Judicial Effectiveness; GI - Government Integrity. } \\
\text { Sources: World Bank, 2018, https://info.worldbank.org/governance/wgi/; } \\
\text { Heritage Foundation, 2019, https://www.heritage.org/index/ranking. }\end{array}$} \\
\hline
\end{tabular}

As for the working of informal norms in the SEE region, we operationalise them as reliance on "your trusted people and connections in important places" for problem solving in particular contexts and assess their prevalence and functions (Efendic \& Ledeneva, 2020). The functioning of informal norms is not possible without enforcement (peer pressure) and supporting channels to access resources (informal networking), hence, the operationalisation of reliance on "trusted people and connections" (social networks, trust networks or social capital) is done through the use of informal networks. The emphasis is made on use of networks, rather than on the network constitution. The strength of the informal institution of "your trusted people and connections" is tested in the times of need and the data reveal the key importance of the instrumentality of informal networks in the SEE region.

And more generally, one could argue that informal networks are the best proxy for channelling and facilitation of interaction between formal and informal institutions: not only in the bottom-

\footnotetext{
${ }^{5}$ Appendix 1 reports more details about the sample and how both types of data were collected.
} 
up direction, but also top-down. If one accepts that the formal rules are co-dependent with informal norms, then informal networks within formal organisations are just as essential for promoting top-down agendas: "(...) the discretionary zone in the interpretation and application of formal rules may itself be governed by a set of informal 'meta-rules' that tell civil servants when they can relax, suspend or modify rules, in respect of which persons, and in which circumstances" (Ledeneva et al., 2018: 474-475).

In terms of ideal types, in universalist cultures, where formal rules are enforced and followed more or less universally, the informal networks support or re-enhance these formal rules. In other words, informal networks are relationship -based but not aimed at rule-bending, problemsolving, or getting competitive advantage - they are conducive of the predominantly universalist values (in this case informal norms and formal rules play a complementary role to each other). Institutional frameworks within which this is possible are characterised by a stage of development where resources are there to exclude predatory forms of exploitation and fierce competition over resources at the expense of the public good.

\section{3a. Informal networking by general public in SEE}

The INFORM survey captures the informal practice of "having its trusted people and connections" by asking the following: Q1. In our society if you want to get the job done, you always have to have your trusted people in important places and to have connections responses are in the range 1 not at all accurate to 10 completely accurate. Over $35 \%$ of respondents in SEE takes the maximum value of 10 to indicate that having "trusted people and connections" at different places in these societies is essentially important. Around $50 \%$ of respondents chose the value 8-10 (Figure 3). This suggests that this type of informal norm is perceived as widespread and useful, with almost no difference between SEE countries. Similar responses are obtained for the question which asks to what extent is important to have large informal networks in this society $(\mathrm{Q} 2$. On the scale from 1 to 10 please rate how important is to you to have a large number of people that you can rely on - 1 means not important at all, 10 means very important). Some $36 \%$ chose the maximum value of 10 , while the mean value is 7.1 , with slight variations between the countries.

Figure 3. "Trusted people and connections" in SEE countries 


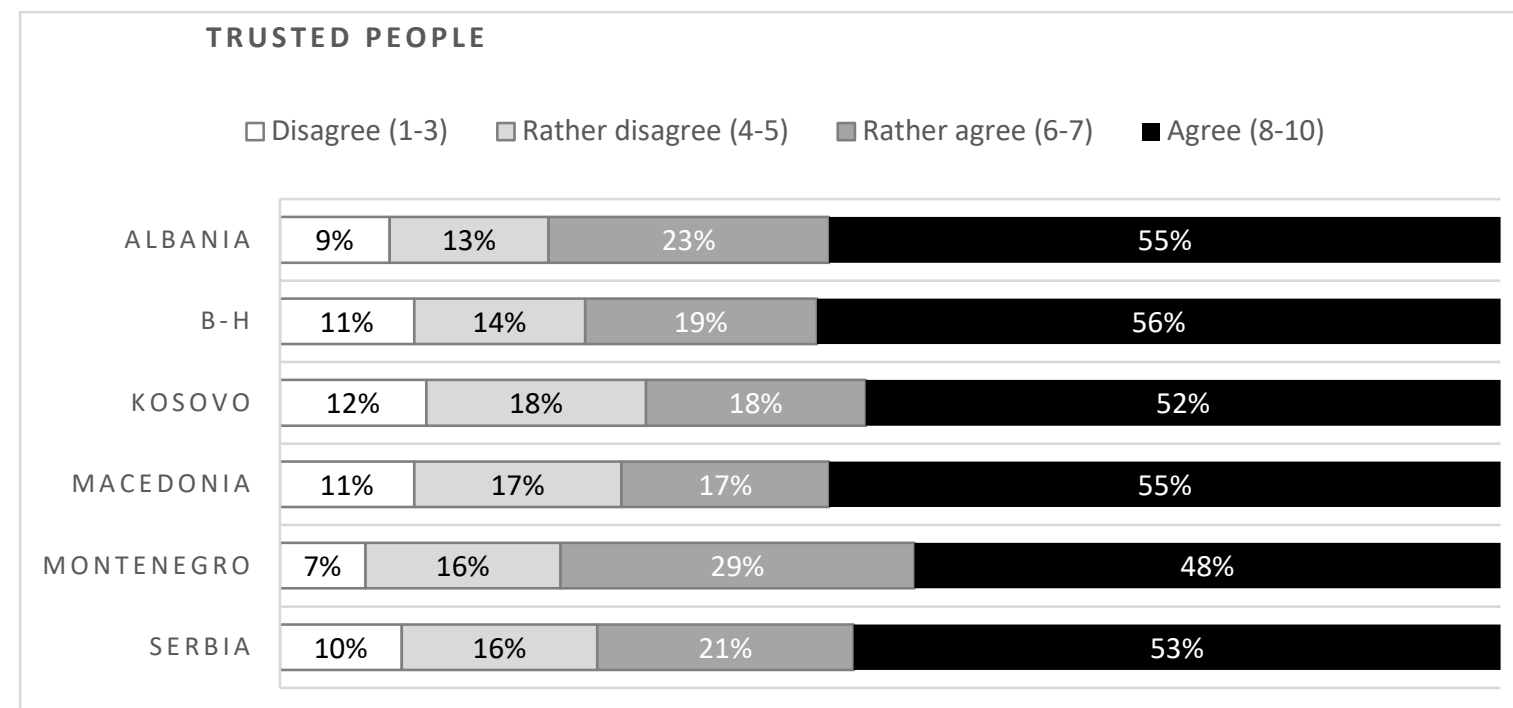

Source: INFORM, 2017

When respondents reflect on their experience of formal institutions and trust in them (Q3. Based in your own experience, what is your trust in state institutions in our country, like courts, police, governments, ... -1 no trust at all to 10 complete trust), their answers are almost the reverse. The most frequently given answer is the lowest level of trust $-1(22 \%)$, and the mean is 4.2 . There are a bit more variations between SEE countries on this question, with the lowest trust recorded in Bosnia and Herzegovina (3.5). This suggests quite low level of trust in formal institutions and high incidence of reliance on personal networks and 'trusted people and connections' (Figure 3). Thus, it would be important to know if personal trust is used as a solution to the lack of trust in formal institutions (Salinas et al., 2018). Consequently, to know whether the trust in state institutions (which we use as a proxy for efficiency of formal institutions, based on the experience of respondents with these institutions) is associated with the informal norm of relying on "trusted people and connections," or with the use of "informal networking" through which this informal norm is operationalised, we need a model that can enable us to investigate these complex relationships between formality and informality.

Following similar research by Efendic at al. (2011) on the link between confidence in formal and reliance on informal institutions in $\mathrm{BiH}$, we assume that people's experience with formal institutions and use of informal norms of reliance on connections and informal networking may differ. The difference can relate to both observable personal characteristics that we can control for - age, gender, marital status, education, economic performance, areal of living, and countries - and unobservable personal characteristics that we cannot control for directly (which might lead to the possibility of the omitted variable bias). In the context of SEE, possible candidates for unobserved factors are likely to be specific cross-cultural issues and influence of cultural diversity. The implication for our modelling strategy is that we need to control both: whether observable or not, both factors affect the informal-formal link that we investigate (inclusive of the immeasurable sociability skills and personal charm).

If there is an unobservable bias that has a systematic influence on the link formal-informal institutions, which is very likely due to the complexity discussed earlier, we hope to eliminate 
it by allowing the error term to be correlated between equations: i.e. assuming (and testing) that this correlation will capture unobservable influence. A model possessing such properties is the 'system of regression equations' (Greene, 2003), which in our case may be estimated as a seemingly unrelated bi-variate probit model - SUPM. The SUPM is a system of equations in which the error terms are allowed to be correlated between equations (Gould et al., 2006), while common observed determinants are included in both regressions. The SUPM allows for a more complex (seemingly unrelated) pattern of joint determinations than simple simultaneity.

The relationship between efficiency of formal institutions and reliance on "trusted people and connections" via informal networking is modelled implicitly through the unobserved correlations in the error terms (Heij et al., 2004). We expect that some culturally rooted factors, for example, "Balkans mentality" that is mentioned by some of our informants (e.g. CRO_26 quote in the next section), might bias all regressions in our study, while this approach should capture it. In addition, we explicitly model the interaction by controlling for common observable variables in the system, and use conservative approach to estimate cluster robust model (with municipalities as clusters). The visual illustration of the model is shown in Figure 4 and quantitative results are reported in Appendix 2, while we discuss the main findings on the type of formal-informal interaction.

\section{Figure 4. Visual illustration of the formal-informal interaction model}

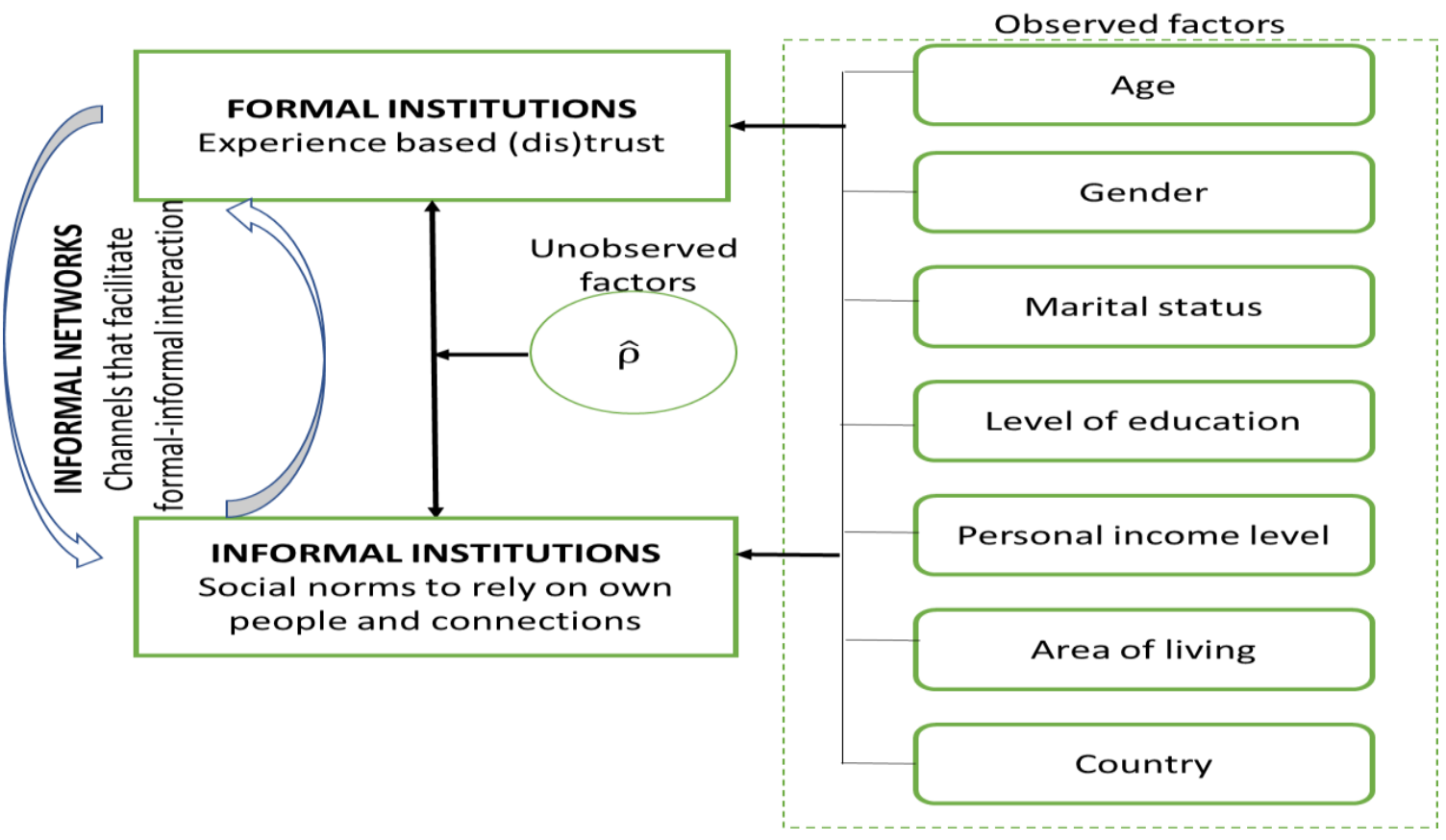

Of particular interest for our interpretation is the Likelihood-ratio (LR) test, which provides a formal statistical check on the validity of the estimated model (or whether the model should be estimated with two independent binary probit equations). The LR tests the null hypothesis that

\footnotetext{
${ }^{6}$ Acronyms for countries are introduced in Appendix 1. CRO_4 means interview number 4 in Croatia. Other countries are, Slovenia - SLO, Croatia - CRO, Bosnia and Herzegovina - BiH, Serbia - SRB, Montenegro - MNG, North Macedonia - MAC, Kosovo - KOS and Albania - ALB
} 
the unobserved influences between the two equations are not associated in the manner suggest by our approach in Figure 4. The outcomes of LR test for the coefficient ' $\hat{\rho}$ ' in Figure 4 yields the p-value of 0.009. Thus, we reject the null hypothesis and conclude that this model is appropriately specified as a system.

The LR test is also informative to check whether formal institutions and informal norms are mutually exogenous (i.e. separate); or, if related endogenous (Fabbri et al., 2004), whether they act as substitute or complement to each other (Efendic et al., 2011). In our case, the test indicates a mutually endogenous relationship between the efficiency of formal institutions and reliance on "trusted people and connections" (Appendix 2, Table A2). According to the negative and significant rho coefficient $(\hat{\rho}=-0.09)$, the two dependent variables are both determined by (unobserved) influences that are negatively correlated across the equations conditional on observed factors in the model. This means that unobserved (e.g. cultural) influences in the first equation, associated with lower trust in formal institutions, are associated with a greater reliance on 'trusted people and connections', enabled by 'informal networking'. The reverse also works: the higher the trust is into the workings of formal institutions, the lower the reliance on 'trusted people and connections'.

If we look at the influence of observable variables (Appendix 2), the effects of education, economic performance of individuals (measured through their personal income), and the country effects are mainly significant in both models that compose our system. The results indicate that more educated individuals and those with higher incomes report more trust towards formal institutions and less use of informal ones. Or more precisely said, those individuals with education lower than the university degree and with lower level of incomes are less trusting towards formal institutions and rely more heavily on informal once (if measured through the concept of "trusted people and connections"). The country effects are also interesting as they report that respondents from all SEE countries in our sample have higher trust in their formal institutions in comparison to Bosnia and Herzegovina (BiH), which is the base category. This is not surprising, as the institutional setup in $\mathrm{BiH}$ is well known for its complexity, on one hand, and inability of political forces to agree on institutional reforms that will lead this country to further institutional prosperity, on the other hand (Williams and Efendic, 2019). However, there are no differences between countries in the use of "trusted people and connections", which suggests that this informal norm is more persistent and less diverse in the region than perceptions regarding the efficiency of formal institutions.

Overall, in our survey, people's trust in formal institutions arise from their experience of constraints of formal institutions (see the related question) and, hence, correspond to the actual enforcement and performance of formal institutions. Given the under-enforcement and overregulation features of formal institutions in SEE region (Gordy and Efendic, 2019), it is logical to presume that the substitutive role of informal institutions is essential, and probably more persistent. It is often suggested in the literature that no society operates without trust. So if trust into formal institutions is low, the personalised trust would compensate for, or substitute for it. On the basis of our data, we can offer further interpretation in that vein: 
- First, the reliance on the informal norm of "trusted people and connections" is empowered by the inefficiency of formal rules and procedures.

- Second, the instrumentality of "informal networking" that channels pressure to circumvent formal rules and procedures grows together with the inefficiency of formal institutions.

Although not in themselves surprising, our findings confirm a substituting type of interaction between formal and informal institutions in SEE. Further tests are needed to be able to illustrate empirically that informal norms are more stable and more difficult to change (i.e. circles of trusted people and connections are fairly closed and difficult to acquire).

\section{3.b. Informal networking by entrepreneurs in SEE}

Our qualitative in-depth analysis of informal networking among entrepreneurs seem to corroborate the possibility that while the general public is more compliant with the informal norms of reliance on 'trusted people and connections', the entrepreneurs are more dynamic in their attitudes: that develop more informal networks, invest in them but also challenge their burden (Efendic \& Ledeneva, 2019). Indeed, the entrepreneurship literature reports that entrepreneurs tend to develop compensating mechanisms to operate their business when they need to address the challenges arising from emerging markets and imperfect institutional enforcements (Salinas et al., 2018; Ge et al., 2019). Entrepreneurial activity is thus affected by the formal and informal institutional voids and their interaction (Webb et al., 2019). However, they are also first to recognise the burden of doing so and other limitations associated with informal networking. Although networks might be more open, outreaching and give a better return on investment (supporting weak ties is more cost-effective than strong ties), they are also limited in what they can deliver. Our respondents believe that some problems can only be solved on the basis of strong bonds of reciprocity, so the informal norm of reliance on "trusted people and connections" has been stressed as important also by entrepreneurs from all SEE countries:

In our society, there is still a system where you cannot make progress without some sort of informal connections, BiH_17 . [Moreover, entrepreneurs believe that if they do not have a proactive position, nothing will change and they will face more challenges]: If you do not have your own informal connections, ... the doors will be closed, SRB_3, and this is because: There are segments in our society where you just have to have informal connections ... you have to have the ear that listens to you in order to get what you need, BiH_10.

What our respondents argue is that connections enable one to "swim in muddy waters", MAC_3, and often help to offset political influences in their business. Some entrepreneurs see that ...corruption is everywhere, SRB_3 and to get what they even deserve by the law, they ...would need informal connections, $\mathrm{BiH} \_4$. This point of relying on informal forms to make the formal rules effective is of key importance to the understanding of the interaction of formal and informal institutions. For outsiders, informal networking may result in loose and open-

\footnotetext{
${ }^{7}$ See the previous footnote for explanation and Appendix 1.
} 
ended associations, but these relationships have to become 'sealed' into tightly-knit circle of trust, support, and reciprocal obligations in order to be truly effective.

One of entrepreneurs from Croatia, educated abroad, has explained the necessity to develop informal networking in order to get in touch with "trusted people" but also for socialisation.

I was educated in the USA, so when I came back here and tried to do everything by the book, I did not fully understand informal networking and did not accept this environment, let's call it "Balkan mentality." This was the case until several years ago when I realized how our system is functioning, and that it was better for me to start socializing and networking more to find my 'trusted people'. I could not progress without them (CRO_2).

What we find throughout the SEE region is that informal networking among entrepreneurs is commonly used, even if varied in scope and kind. On balance, it is business interests that motivates entrepreneurs to participate in informal networking, and much more so than adherence to an informal norm or cultural conformity (Efendic \& Ledeneva, 2020). Although some entrepreneurs acknowledge the necessity to accommodate the mentality of people in this region, their motivation seems proactive and driven by gaining access and creating opportunities, reducing risks and optimising costs. The majority of interviewees argue that informal networks are used primarily to compensate for the failures of formal institutional outcomes - informal networking is used as an efficient mode to cope with burdensome and unnecessary formal institutional challenges; they act as substitutes $\left(\mathrm{BiH} \_1, \mathrm{BiH} \_3, \mathrm{BiH} \_4\right.$, BiH_6, BiH_7, BiH_8, KOS_3, KOS_5, ALB_1, ALB_2, MAC_1, MAC_3, MAC_6, SRB_1, SRB_3, SRB_6, SRB_8).

This investigation suggests that the functioning of informal norms is impossible without channels associated with informal networking. Although informal networks seem to be a biographical by-product, they are costly to establish, maintain and expand - it takes a lifetime of individual effort, time, and resources. The costs of informal networking depend upon network size, which is limited, given the finite nature of individual time and monetary resources. The available literature reports that density of networks has a significant influence on costs; higher density of informal networks lowers transaction costs (Henning, Henningsen \& Henningsen, 2012). Moreover, the structure of networks might influence informal costs differently - network diversity based on race or ethnicity, for example, or networks based on family and friends, or acquaintances (Marmaros \& Sacerdote, 2006; Silk, 2003) all might have different effects on costs.

As for the costs of informal networking in SEE, individuals in the region invest considerable time and financial resources into informal networking (Efendic \& Ledeneva, 2020). The total informal networking cost, the costs of time and money (standardized by the PPP index to equalize prices between different countries) at the monthly level is estimated to be around 100 euros. This level of costs is not to be ignored considering that the average net monthly salary in Western Balkans region is less than 500 Euro (exceptions are Croatia and Slovenia as EU countries in our sample). Our findings also suggest that the estimated (opportunity) costs of time are greater than the reported monetary costs and higher among entrepreneurs. 
The complexity of conversion of informal networks into circles of trusted people and connections require qualitative research, and this will help explain the interaction between the formal institutions and informal institutions further, especially with respect of the pressure and enforcement that people of the circle are capable of imposing on each other. The importance of being networked, which can be estimated in quantitative terms, has to be coupled with the qualitative analysis of the grip that "trusted people and connections" have over each other. Without understanding of this so-called lock-in effect, it is not possible to model economic behaviour in particularistic contexts.

\section{Conclusion}

In this chapter, we have reviewed the existing literature on formal and informal institutions and devised a model for conceptualising the formal-informal interaction, and to empirically test the role of informal institutions in transition. We address the questions, "what works when the formal institutions do not?' and 'to what extent do formal institutions (operationalised as trust in formal rules and procedures) constitute real constraints in SEE societies with a strong hold of personalised trust and reliance on personal connections.' We scrutinised the existing typologies of formal and informal institutions and the INFORM model of the interaction between formal and informal institutions. We have established the advantages of the INFORM model for empirical testing as follows. Firstly, it works for transitional contexts where formal rules are often fast-changing and might not necessarily constitute constraints. Secondly, it allows for variation in the pressure of constraints, both formal and informal, which is essential for accounting for the transaction costs. Thirdly, it distinguishes between informal institutions (informal norms) and other informal regularities (informal practices). Finally, it integrates informal networks as channels of interaction between formal and informal institutions. Although such theoretical adjustment in modelling the interaction between formal and informal institutions might be of value in its own right, we have undertook to test it empirically with both quantitative and qualitative data.

To answer the questions on the role of informal institutions in transition we rely on survey evidence from eight countries of South East Europe. When formal rules fail to be efficient, social norms of reliance on "trusted people and connections" seem to predominate as a default (substitutive) option. Reliance on informal norms and investing time and money into facilitating channels, informal networking, to 'correct' the failures of the formal institutions in the SEE region is so common that it makes us conclude on the predominantly substitutive role of informal institutions. Our findings hold for the general public, as well as for entrepreneurs, with entrepreneurs playing a more active role in informal networking. While these relationships are perceived to offset defects in the workings of formal institutions, and are thus used for instrumental purposes, they are also an enactment of trust and sociability in daily life, thus holding societies together vis-à-vis challenges of transition, crises or post-war development. The open question for policy-makers is how to re-orient informal networks, make them more open and conducive of norms coherent with the formal rules and the more universal idea of public good. We establish a further need to investigate the 'capabilities and functionings' of informal networking and their role in the workings of formal institutions. 


\section{References}

Acemoglu, D. 2009. Persistence and Change in Institutions, The Marshall Lectures 2008-09, Seminar at Cambridge University, 10-11 th February 2009.

Acemoglu, D. and Robinson, J. A. 2010. The Role of Institutions in Growth and Development. Review of Economics and Institutions 1(2): 1-33

Aidis, R., Estrin, S., \& Mickiewicz, T. 2008. Institutions and entrepreneurship development in Russia: a comparative perspective. Journal of Business Venturing 23(6): 656-672.

Alesina, A. and Giuliano, P. 2013. Family Ties. NBER Working Paper No. 18966, April 2013.

Aliyev, H. 2015. Post-Soviet informality: towards theory-building. International Journal of Sociology and Social Policy 35(3/4): 182-198.

Alston, L. J. 1996. Empirical work in institutional economics: an overview. In Alston, L. J., Eggertsson, T. and North, D. C. (eds). 1996. Empirical Studies in Institutional Change, Cambridge: Cambridge University Press.

Andersson, D. E. 2008. Property Rights, Consumption and the Market process - New Horizons in Institutional and Evolutionary Economics. Cheltenham, UK and Northampton, MA, USA: Edward Elgar.

Baez-Camargo, C., \& Ledeneva, A. 2017. Where does informality stop and corruption begin? Informal governance and the public/private crossover in Mexico, Russia and Tanzania. The Slavonic and East European Review 95(1): 49-75.

Blundo, G., de-Sardan, J.P.O., Arifari, N. B., \& Alou, M.T. 2013. Everyday Corruption and the State: Citizens and Public Officials in Africa (1 edition; J.P.O. de Sardan, Ed.). Chicago: Zed Books.

Brousseau, E. \& Glachant, J. M. 2008. New Institutional Economics - A Guidebook. Cambridge: Cambridge University Press.

Casson, M. C., Della Giusta, M. and Kambhampati, S. U. 2010. Formal and informal institutions and development. World Development 38(2): 137-141.

Coase, R.H. 1937. The Nature of the Firm. Economica 4(16): 386-405.

Cveticanin, P. (ed.) 2012. Social and Cultural Capital in Serbia. Nis: Centre for Empirical Cultural Studies of South-East Europe.

De Soto, H., 1989. The Other Path: The Invisible Revolution of the Third World. London: IB Tauris.

De Soto, H., 2000. The Mystery of Capital: Why Capitalism Triumphs in the West and Fails Everywhere Else. New York: Basic books.

Dimitrova, Antoaneta L. 2010. The new member states of the EU in the aftermath of enlargement. Do new European rules remain empty shells?. Journal of European Public Policy 17(1): 137-148.

Easterly, W. 2008. Design and reform of institutions in LDCS and transition economies. Institutions: Top Down or Bottom Up?. American Economic Review: Papers \& Proceedings 98 (2): 95-99.

Ebner, A. 2008. Institutional Evolution and the Political Economy of Governance. In Ebner, A. and Beck, N. (eds), 2008. The Institutions of the Market-Organizations, Social Systems, and Governance. Oxford: Oxford University Press. 
Efendic, A. 2016. Emigration intentions in a post-conflict environment: evidence from Bosnia and Herzegovina. Post-Communist Economies 28(3): 335-352.

Efendic, A. and Ledeneva, A. 2019. The cost of informal networking in the Western Balkans region matters! In: Gordy, E. and Efendic, A. (eds.) Meaningful Reform in the Western Balkans - Between Formal Institutions and Informal Practices. Bern: Peter Lang AG, pp. 85-101.

Efendic, A. and Ledeneva, A. 2020. The importance of being networked: The costs of informal networking in the Western Balkans region. Economic Systems (forthcoming).

Efendic, A. and Pugh, G. 2015. Institutional effects on economic performance in post-socialist transition: a dynamic panel analysis. Acta Oeconomica 65(4): 503-523.

Efendic, A., Pugh, G. \& Adnett, N. 2011. Confidence in formal institutions and reliance on informal institutions in Bosnia and Herzegovina - an empirical investigation using survey data. Economics of Transition 19(3): 521-540.

Eggertsson, T. 1996 A note on the economics institutions. In Alston, L. J., Eggertsson, T. and North, D. C. (eds) 1996. Empirical Studies in Institutional Change. Cambridge: Cambridge University Press.

Estrin, S. \& Prevezer, M. 2011. The role of informal institutions in corporate governance: Brazil, Russia, India, and China compared. Asia Pacific Journal of Management 28(1): 41-67.

Fabbri, D., Monfardini, C. and Radice, R. .2004.Testing exogeneity in the bivariate probit model: Monte Carlo evidence and an application to health economics. Working Papers No. 514, Bologna: Dipartimento Scienze Economiche, Universita' di Bologna.

Fang, T., 2012. Yin Yang: A new perspective on culture. Management and organization Review 8(1): 25-50.

Fukuyama, F., Dinello, N. and Popov, V., 2007. Development and the limits of institutional design. Political Institutions and Development: Failed Expectations and Renewed Hopes, 21.

Furubotn, E. G. and Richter, R. 2005. Institutions \& Economic Theory, The Contribution of the New Institutional Economics. Second Edition, Ann Arbor: The University of Michigan Press.

Ge, J., Carney, M. and Kellermanns, F. 2019. Who fills institutional voids? Entrepreneurs' utilization of Political and family ties in emerging markets. Entrepreneurship Thoery and Practice 43(6): 1124-1147.

Ginsburg, T. and Simpser, A. (eds). 2013. Constitutions in Authoritarian Regimes. Cambridge: Cambridge University Press.

Gordy, E. and Efendic, A. 2019. Meaningful reform in the Western Balkans - Between Formal Institutions and Informal Practices. Bern: Peter Lang.

Gould, W., Pitblado, J. and Sribney, W. 2006. Maximum Likelihood Estimation with Stata.

Granovetter, M., 1985. Economic action and social structure: The problem of embeddedness. American Journal of Sociology 91(3): 481-510.

Greene, W. H. 2003. Econometric Analysis. 5th edn, Princeton, NJ: Prentice Hall.

Grødeland, A. B. 2013. Public perceptions of corruption and anti-corruption reform in the Western Balkans. Slavonic \& East European Review 91(3): 535-598.

Grzymala-Busse, A. 2010. The best laid plans: The impact of informal rules on formal institutions in transitional regimes. Studies in Comparative International Development 
45(3): $311-333$.

Harriss, J. 2008. Explaining economic change: The relations of institutions, politics, and culture. In Ebner, A. and Beck, N. (eds) 2008. The Institutions of the Market Organizations, Social Systems, and Governance. Oxford: Oxford University Press

Heij, C., de Boer, P., Franses, P. H., Kloek, T. and van Dijk, H. K. 2004. Econometric Methods with Applications in Business and Economics. Oxford: Oxford University Press.

Helmke, G. \& Levitsky, S. 2004. Informal Institutions and Comparative Politics: A research agenda. Perspective on Politics 2(4): 725-740.

Henig, D., \& Makovicky, N. 2017. Economies of favours after socialism: A comparative perspective. Oxford: Oxford University Press.

Henning, C. H. C. A., Henningsen, G., \& Henningsen, A. 2012. Networks and transaction costs. American Journal of Agricultural Economics 94(2): 377-385.

Hinings, C. R. and Malhotra, N. 2008. Change in institutional fields. In Ebner, A. and Beck, N. (eds) 2008. The Institutions of the Market - Organizations, Social Systems, and Governance. Oxford: Oxford University Press.

Hodgson, G. M. 2006. What are institutions?. Journal of Economic Issues XL(1): 1-25.

Hudson, D., \& Marquette, H. 2015. Mind the gaps: what's missing in political economy analysis and why it matters. In: Alan Whaites, Eduardo Gonzalez, Sara Fyson, Graham Teskey (eds) 2015. A Governance Practitioner's Notebook, 16: 67-82. OECD.

Institute Discussion Papers No. 99-004/2, Rotterdam: Tinbergen Institute.

Jutting, J. 2003. Institutions And Development: A Critical Review. OECD Working Paper No. 210.

Khan, M. 1995. State failure in weak states: A critique of New Institutionalists Explanations. In Harriss, J., Hunter, J. and Lewis, C. M. (eds) 1995. The New Institutional Economics and Third World Development. London: Routledge.

Knowles, S. \& Weatherston, C. R. 2006. Informal Institutions And Cross-Country Income Differences. Dunedin: University of Otago, Department of Economics.

Lauth, H. J. 2007. Informal institutions and democracy. Democratization 7(4): 21-50.

Ledeneva, A. with Bailey, A., Barron, S., Curro, C. \& Teague, E. (eds.). 2018. The Global Encyclopaedia of Informality. London: UCL Press.

Ledeneva, A. 2008. Informal networks in post-communist economies: A "topographic map." In Thomas Lahusen, Peter H. Solomon Jr. (eds.) (2008) What is Soviet Now? Identities, Legacies, Memories. Berlin: Lit Verlag, pp.101-134.

Ledeneva A. 2006. How Russia Really Works. Informal Practices in Politics and Business. Cornell University Press.

Ledeneva, A. 2001. Uwritten Rules: How Russia really Works. London: CER.

Ledeneva, A. V. 1998. Russia's Economy of Favours: Blat, Networking and Informal Exchange. Cambridge: University Press.

Marmaros, D., and Sacerdote, B. 2006. How Do Friendships Form?. The Quarterly Journal of Economics 121(1): 79-119.

Minbaeva, D., Muratbekova-Touron, T., Horak, S. and Ledeneva, A. 2020. Explaining continuity and change in informal institutions: the role of informal network. Forthcoming in AMP. For presentation at the Academy of International Business 2020 in Miami, Florida. 
Moers, L. 1999. How important are institutions for growth in transition countries?. Tinbergen Möllering, G. 2014. Trust, calculativeness, and relationships: A special issue 20 years after Williamson's warning. Journal of Trust 4 (1): 1-21.

Mungiu-Pippidi, A. 2015. The Quest for Good Governance: How Societies Develop Control of Corruption. Cambridge: Cambridge University Press.

Nelson, R. R. 2008. Co-evolution of technologies and institutions in market economies. In Ebner, A. and Beck, N. (eds) 2008. The Institutions of the Market-Organizations, Social Systems, and Governance. Oxford: Oxford University Press

Newton, S. 2017. The Constitutional Systems of the Independent Central Asian States: A Contextual Analysis. Oxfrod: Hart.

North, D. 1991. Institutions. Journal of Economic Perspectives 5 (1): 97-112.

North, D. C. 1990. Institutions, institutional change and economic performance. Cambridge: University press.

North, D. C. 1995. The new institutional economics and third world development. In J. Harriss, J. Hunter, \& C. M. Lewis. (Eds.), The New Institutional Economics And Third World Development: 17-26. New York: Routledge.

Nye, J. 2008. Institutions and the Institutional Environment. In Brousseau, E. and Glachant Jean-Michel (eds). 2008. New Institutional Economics - A Guidebook. Cambridge: Cambridge University Press.

Opper, S. 2008. New Institutional economics and its application on transition and developing economies. In Brousseau, E. and Glachant Jean-Michel (eds) 2008. New Institutional Economics - A Guidebook. Cambridge: Cambridge University Press.

Pejovich, S. 1999. The effects fo interaction of formal and informal institutions on social stability and economic development. Journal of Markets and Morality 2(2): 164-181.

Pejovich, S. 2008. Law, Informal Rules and Economic Performance, The Case of Common Law. Cheltenham, UK/Northampton, MA, USA: Edward Elgar.

Polese, A., 2015. Informality crusades: Why informal practices are stigmatized, fought and allowed in different contexts according to an apparently ununderstandable logic. Caucasus Social Science Review 2(1): 1-26.

Pollitt, M. 2002. The economics of trust, norms, and networks. Business Ethics: A European Review 11(2): 119-128.

Raiser, M. 2001. Informal Institutions, Social Capital and Economic Transition: Reflections on a Neglected Dimension. In Giovanni Andrea Cornia and Vladimir Popov (eds). 2001. Transition and Institutions: The Experience of Gradual and Late Reformers. Oxford: Oxford University Press.

Redmond, W. H. 2005. Process of Gradual Institutional Drift. Journal of Economic Issues, Vol. XXXIX, No. 2, pp. 501-509.

Sakwa, R. 2007. Constitutionalism and Accountability in Contemporary Russia: the Problem of Displaced Sovereignty. In: Gordon Smith and Robert Sharlet. (eds). 2007. Russia and its Constitution: Promise and Political Reality. Martinus Nijhoff Publishers.

Salinas, A., Muffatto, M. and Alvarado, R. 2018. Informal institutions and informal entrepreneurial activity: new panel data evidence from Latin American countries. Academy of Entrepreneurship Journal 24(4): 1-17.

Scott, R. 2004. Reflections on a Half-Century of Organizational Sociology. Annual Review of 
Sociology 30: 1-21.

Searle, J. R. (2005) What is an institution? Journal of Institutional Economics 1(1): 1-22.

Sen, A. K., 1992. Inequality Reexamined. Oxford: Oxford University Press.

Shirley, M. M. 2008. Institutions And Development. Cheltenham, UK and Northampton, MA, USA: Edward Elgar Publishing Limited.

Silk, J.B. 2003. Cooperation without counting. In P. Hammerstein (Ed.) 2003. Genetic and Cultural Evolution of Cooperation, pp. 37-54. Boston: The MIT Press.

Stanojevic, D., Stokanic, D. 2014. The importance of clientelism and informal practices for employment among political party members after 2000s - An explorative enquiry. In Cveticanin, P., Mangova, I. and Markovikj N. (eds), A Life for Tomorrow - Social Transformations in South-East Europe. Skopje: Institute for Democracy "Societas Civilis" Skopje

Tabellini, G. 2010. Culture and institutions: economic development in the regions of Europe, Journal of the European Economic Association 8(4): 677-716.

Texas: STATA Press.

Tonoyan, V., Strohmeyer, R., Habib, M. and Perlitz, M. 2010. Corruption and entrepreneurship: how formal and informal institutions shape small firm behaviour in transition and mature markets. Entrepreneurship Theory and Practice, September 2010: 803-832.

Tsai, K. S. 2006. Adaptive informal institutions and endogenous institutional change in China. World Politics 59(1): 116-141.

Wallis, J. J., \& North, D. 1986. Measuring the Transaction Sector in the American Economy, 1870-1970. In Long-term factors in American economic growth, pp. 95-162. Retrieved from https://econpapers.repec.org/bookchap/nbrnberch/9679.htm

Webb, J. W. Khoury, T. A. and Hitt, M. A. 2019. The influence of formal and informal institutional voids on entrepreneurship. Entrepreneurship Theory and Practice (september 2010): 803-831.

Williams, N. and Efendic, A. 2019. Internal displacement and external migration in a postconflict economy: Perceptions of institutions among migrant entrepreneurs. Journal of International Entrepreneurship 17(4): 558-585.

Williams, N., \& Vorley, T. 2015. Institutional asymmetry: How formal and informal institutions affect entrepreneurship in Bulgaria. International Small Business Journal: Researching Entrepreneurship 33(8), 840-861.

Williamson, C. R. 2009. Informal institutions rule: institutional arrngaments and economic performance. Public Choice 139: 371-387.

Williamson, C. R. and Kerekes, C. B. 2011. Securing private property: formal versus informal institutions. Journal of Law and Economics 54(3): 537-572.

Williamson, O. E. 1993. Calculativeness, trust, and economic organization. The Journal of Law and Economics 36: 453-486.

Williamson, O. E. 2000. The New institutional economics: taking stock, looking ahead. Journal of Economic Literature Vol. XXXVIII, September 2000: 595-613. 


\section{Funding}

This research has been produced within INFORM project. This project has received funding from the European Union's Horizon 2020 research and innovation programme under grant agreement No 693537.

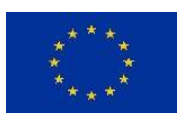


Appendix

\section{Appendix 1}

\section{Explanation of the SEE sample and the data}

We analyse INFORM data ${ }^{8}$ collected in six South East European countries: Albania (ALB), Bosnia and Herzegovina (BiH), Kosovo (KOS), North Macedonia (MAC), Montenegro (MNG), and Serbia (SRB) over the period March - June 2017. A multi-stage random (probability) sampling methodology ensured representative samples in the data collection. In every household, the 'nearest birthday' rule was applied to select respondents for interviewing. Every subsequent address was determined by the standard 'random route' procedure. The survey was implemented by a professional research agency operating in all WB countries and implementing the survey simultaneously in all countries. The dataset comprises 6,040 respondents from six countries, with over 1,000 observations per country. The survey covers a variety of topics related to formal institutions and informal norms in the WB countries.

Our qualitative investigation included the case of entrepreneurs from small and medium scale businesses in eight SEE countries (including Croatia-CRO, and Slovenia-SLO, in this sample). Our point of entry - the entrepreneurs - enables us to explore the role of informal norms, as informal networking, in more detail, because entrepreneurs are the outsiders of the formal hierarchical structures, such as state or public services, but depend on them, so they have both an expertise and willingness to speak about using their contacts. The interviews were conducted by local INFORM researchers over the period November 2016 - February 2017. ${ }^{9}$ Majority of interviews were recorded with consent of the interviewees; anonymised; converted into transcripts; and coded for the purposes of comparative analysis. Our sample includes 70 interviews ${ }^{10}$, which is not representative of SME sector and puts certain limitations on the interpretation of results. However, the illuminating insights and research questions in this article provide valuable hypothesis for assessing the implications of informal networking in future research.

\footnotetext{
${ }^{8}$ INFORM is a EU supported project that brought together teams from eight South East European countries to conduct multidisciplinary social science research on formal and informal institutions. The three-year research project, launched in March 2016, was carried out in the framework of the Horizon 2020 programme. 40 researchers from SSE region participated in this project. We thank to all researchers from national teams who helped in gathering the data for particular countries of SEE.

${ }^{9}$ This research relies on the data collected in one point of time (2017); hence, we do not observe longitudinal nor panel data. This approach makes limitation generally acknowledged for the most of cross-sectional research, as we are not able to uncover any dynamics nor to be completely sure about the potential concern on causality.

${ }^{10}$ The questions were tested in five pilot interviews with entrepreneurs in $\mathrm{BiH}$ in September 2016 and modified accordingly. They covered five major topics: information about the main line of business; size and structure (density, centrality) of informal networks; costs of informal networks; and general functioning of these networks. Overall, we did not have any major challenges in carrying out these interviews. The majority of respondents were willing to talk about these issues, although some were rather terse in their responses, while some started talking only after the recorder was turned off. INFORM researchers have conducted five interviews in ALB, sixteen in $\mathrm{BiH}$, five in CRO, five in KOS, ten in MAC, nine in SRB and twenty in SLO.
} 
List of participants/interviewees from the business sector in SEE

\begin{tabular}{|c|c|c|c|c|}
\hline Respondent & Type of business & $\begin{array}{c}\text { Company } \\
\text { age }\end{array}$ & $\begin{array}{c}\text { Respondent } \\
\text { age - } \\
\text { category }\end{array}$ & $\begin{array}{l}\text { Number of } \\
\text { employees }\end{array}$ \\
\hline BiH_1 & Civil engineering construction & $21-25$ & $51-60$ & $11-50$ \\
\hline BiH_2 & Automotive & $0-5$ & $31-40$ & $0-10$ \\
\hline BiH_3 & Production of polymers & $16-20$ & $51-60$ & $51-250$ \\
\hline BiH_4 & Land and real estate agency & $0-5$ & $21-30$ & $0-10$ \\
\hline BiH_5 & Accounting agency & $0-5$ & $21-30$ & $0-10$ \\
\hline BiH_6 & Business/start-up hub & $0-5$ & $21-30$ & $11-50$ \\
\hline BiH_7 & Business/start-up hub & $0-5$ & $21-30$ & $11-50$ \\
\hline BiH_8 & Association of entrepreneurs & $16-20$ & $51-60$ & $0-10$ \\
\hline BiH_9 & Association of entrepreneurs & $16-20$ & $31-40$ & $0-10$ \\
\hline BiH_10 & Civil engineering construction & $36-40$ & $51-60$ & $0-10$ \\
\hline BiH_11 & Family winery & $36-40$ & $41-50$ & $0-10$ \\
\hline BiH_12 & Wood instigators production & $0-5$ & $31-40$ & $0-10$ \\
\hline BiH_13 & Catering industry & $16-20$ & $41-50$ & $51-250$ \\
\hline BiH_14 & Catering industry & $0-5$ & $21-30$ & $0-10$ \\
\hline BiH_15 & Private university & $0-5$ & $31-40$ & $0-10$ \\
\hline BiH_16 & Mobile store and Landscaping company & $0-5$ & $21-30$ & $0-10$ \\
\hline MAC_1 & Healthy food stores & $0-5$ & $21-30$ & $11-50$ \\
\hline MAC_2 & Hotel & $11-15$ & $31-40$ & $11-50$ \\
\hline MAC_3 & Marketing agency & $16-20$ & $41-50$ & $11-50$ \\
\hline MAC_4 & Accounting agency & $21-25$ & $61-70$ & $0-10$ \\
\hline MAC_5 & Dairy factory & $11-15$ & $51-60$ & $11-50$ \\
\hline MAC_6 & Catering industry & $26-30$ & $41-50$ & $11-50$ \\
\hline MAC_7 & Online/web shopping company & $0-5$ & $31-40$ & $11-50$ \\
\hline MAC_8 & Private high school & $6-10$ & $31-40$ & $11-50$ \\
\hline MAC_9 & Drugs and medicine distribution & $21-25$ & $41-50$ & $0-10$ \\
\hline MAC_10 & Metallurgy company & $21-25$ & $31-40$ & $0-10$ \\
\hline SLO_1 & Service sector & $0-5$ & $31-40$ & $0-10$ \\
\hline SLO_2 & Service sector - house maintenance & $6-10$ & $41-50$ & $0-10$ \\
\hline SLO_3 & Service sector - mechanic & $0-5$ & $41-50$ & $0-10$ \\
\hline SLO_4 & Restaurant & $0-5$ & $41-50$ & $0-10$ \\
\hline SLO_5 & Service sector - electrician & $21-25$ & $51-60$ & $0-10$ \\
\hline SLO_6 & Research institute & $0-5$ & $31-40$ & $0-10$ \\
\hline SLO_7 & Catering industry & $16-20$ & $51-60$ & $11-50$ \\
\hline SLO_8 & Restaurant & $0-5$ & $31-40$ & $0-10$ \\
\hline SLO_9 & Marketing agency & $6-10$ & $31-40$ & $0-10$ \\
\hline SLO_10 & Marketing agency & $0-5$ & $31-40$ & $0-10$ \\
\hline SLO_11 & Computer shop & $0-5$ & $21-30$ & $0-10$ \\
\hline SLO_12 & Service sector - hairdressing & $26-30$ & $41-50$ & $0-10$ \\
\hline SLO_13 & Wood industry & $26-30$ & $51-60$ & $0-10$ \\
\hline SLO_14 & Cosmetic industry & $6-10$ & $21-30$ & $11-50$ \\
\hline SLO_15 & Service sector - hairdressing & $0-5$ & $21-30$ & $0-10$ \\
\hline SLO_16 & Farming & $11-15$ & $11-20$ & $0-10$ \\
\hline SLO_17 & Power distribution & $6-10$ & $41-50$ & $11-50$ \\
\hline SLO_18 & Plastic industry for construction & $16-20$ & $51-60$ & $0-10$ \\
\hline
\end{tabular}




\begin{tabular}{|c|c|c|c|c|}
\hline SLO_19 & Internet shop & $16-20$ & $41-50$ & $11-50$ \\
\hline SLO_20 & Service sector - mechanic & $0-5$ & $31-40$ & $0-10$ \\
\hline SRB_1 & Production of plastic derivate & $6-10$ & $31-40$ & $11-50$ \\
\hline SRB_2 & Health industry - stomatology & $6-10$ & $31-40$ & $0-10$ \\
\hline SRB_3 & Catering industry & $6-10$ & $31-40$ & $0-10$ \\
\hline SRB_4 & Service sector - hairdressing & $21-25$ & $51-60$ & $0-10$ \\
\hline SRB_5 & Private music school & $0-5$ & $41-50$ & $0-10$ \\
\hline SRB_6 & Design agency & $6-10$ & $31-40$ & $0-10$ \\
\hline SRB_7 & Cosmetic industry & $11-15$ & $51-60$ & $0-10$ \\
\hline SRB_8 & Tectonics sector & $11-15$ & $51-60$ & $0-10$ \\
\hline SRB_9 & Purchase and processing of milk & $6-10$ & $51-60$ & $51-250$ \\
\hline ALB_1 & Private high school & $0-5$ & $41-50$ & $51-250$ \\
\hline ALB_2 & Automotive & $0-5$ & $41-50$ & $0-10$ \\
\hline ALB_3 & IT company & $0-5$ & $41-50$ & $11-50$ \\
\hline ALB_4 & Trade, industrial materials & $16-20$ & $41-50$ & $11-50$ \\
\hline ALB_5 & Printing house & $11-15$ & $41-50$ & $11-50$ \\
\hline CRO_1 & Distribution of electric materials & $0-5$ & $41-50$ & $0-10$ \\
\hline CRO_2 & Marketing agency & $6-10$ & $31-40$ & $11-50$ \\
\hline CRO_3 & Hotel & $0-5$ & $51-60$ & $11-50$ \\
\hline CRO_4 & IT company & $21-25$ & $41-50$ & $11-50$ \\
\hline CRO_5 & Production of lighting solutions & $6-10$ & $41-50$ & $11-50$ \\
\hline KOS_1 & Production of polymers & $16-20$ & $31-40$ & $11-50$ \\
\hline KOS_2 & Trade company and production & $6-10$ & $41-50$ & $11-50$ \\
\hline KOS_3 & Catering industry & $26-30$ & $51-60$ & $11-50$ \\
\hline KOS_4 & Wood instigators production & $11-15$ & $41-50$ & $0-10$ \\
\hline KOS_5 & Civil engineering construction & $16-20$ & $41-50$ & $11-50$ \\
\hline
\end{tabular}




\section{Appendix 2}

Table A1. Descriptive statistics of the main variables of interest

\begin{tabular}{|c|c|c|c|c|}
\hline Variables & Description & $\begin{array}{l}\text { No. of } \\
\text { observations }\end{array}$ & Mean & $\begin{array}{l}\text { Standard } \\
\text { deviation }\end{array}$ \\
\hline ownlinksd & $\begin{array}{l}\text { Trusted people and connections } 1-10 ; 01 \text { to } 5 ; 1-5 \text { to } \\
10\end{array}$ & 5,943 & 0.74 & 0.44 \\
\hline insttrustd & Trust to institutions $1-10 ; 0-1$ to $5 ; 1-5$ to 10 & 5,876 & 0.29 & 0.45 \\
\hline urban & Area of living; 1-urban, 0 -other & 6,040 & 0.53 & 0.50 \\
\hline married & Marital status; 1-married; 0-other & 5,975 & 0.60 & 0.49 \\
\hline female & Gender; 1-female, 0-male & 6,040 & 0.55 & 0.50 \\
\hline age & Age in years & 6,040 & 46.53 & 17.64 \\
\hline hieduc & Education; 1-university or higher; 0-below university & 6,029 & 0.22 & 0.42 \\
\hline pincome & $\begin{array}{l}\text { Personal income; } 1 \text {-less then } 100 € ; 2-101-200 € ; . . .9 \text { - } \\
\text { over } 1501 €\end{array}$ & 4,341 & 2.89 & 1.63 \\
\hline$m a c$ & Country; 1-North Macedonia, 0-other & 6,040 & 0.17 & 0.37 \\
\hline mng & Country; 1-Montenegro, 0 -other & 6,040 & 0.13 & 0.34 \\
\hline kos & Country; 1-Kosovo, 0-other & 6,040 & 0.15 & 0.36 \\
\hline$a l b$ & Country; 1-Albania, 0-other & 6,040 & 0.15 & 0.36 \\
\hline$s r b$ & Country; 1-Serbia, 0-other & 6,040 & 0.19 & 0.39 \\
\hline$B i H^{*}$ & $\begin{array}{l}\text { Country; } 1 \text {-Bosnia and Herzegovina, } 0 \text {-other } \\
\left({ }^{*} \text { omitted category in the model) }\right.\end{array}$ & 6,040 & 0.21 & 0.40 \\
\hline
\end{tabular}


Table A2. SUPM formal-informal interaction model, cluster-robust estimates

\begin{tabular}{|c|c|c|c|c|}
\hline \multirow[t]{2}{*}{ Variables } & Coefficient & $\mathbf{P}>|\mathbf{z}|$ & Coefficient & $\mathbf{P}>|\mathbf{z}|$ \\
\hline & \multicolumn{2}{|c|}{$\begin{array}{c}\text { DEPENDENT VARIABLE } 1 \text { - } \\
\text { insttrustd }\end{array}$} & \multicolumn{2}{|c|}{$\begin{array}{c}\text { DEPENDENT VARIABLE } 2 \text { - } \\
\text { ownlinksd }\end{array}$} \\
\hline urban & -0.02 & 0.774 & 0.07 & 0.290 \\
\hline married & -0.12 & 0.008 & 0.02 & 0.603 \\
\hline female & -0.05 & 0.302 & -0.03 & 0.572 \\
\hline age & 0.00 & 0.110 & 0.00 & 0.075 \\
\hline hieduc & 0.17 & 0.004 & -0.09 & 0.086 \\
\hline pincome & 0.03 & 0.075 & -0.03 & 0.040 \\
\hline mac & -0.14 & 0.169 & 0.02 & 0.819 \\
\hline$m n g$ & 0.46 & 0.000 & 0.06 & 0.599 \\
\hline kos & 0.21 & 0.052 & -0.10 & 0.413 \\
\hline$a l b$ & 0.47 & 0.000 & 0.08 & 0.533 \\
\hline$s r b$ & 0.32 & 0.001 & -0.03 & 0.766 \\
\hline constant & -0.88 & 0.000 & 0.86 & 0.000 \\
\hline \multicolumn{2}{|c|}{ Number of observations } & \multicolumn{3}{|l|}{4,200} \\
\hline \multicolumn{2}{|c|}{ Cluster-robust estimate } & \multicolumn{3}{|c|}{ Yes, clusters are municipalities } \\
\hline \multicolumn{2}{|c|}{ Coefficient of correlation in the residuals } & \multicolumn{3}{|l|}{$r h o=-0.085$} \\
\hline \multicolumn{2}{|c|}{ Wald test of rho $=0: \operatorname{chi} 2(1)$} & \multicolumn{3}{|l|}{ Prob $>$ chi $2=0.0088$} \\
\hline \multicolumn{2}{|c|}{ The Wald test for joint significance } & \multicolumn{3}{|l|}{ Prob $>$ chi $2=0.0000$} \\
\hline
\end{tabular}

